\title{
Socio-economic resilience of Pidie Jaya to against disaster in the terms of national security
}

\author{
Riskina Tri Januarti ${ }^{1 *}$ Heridadi $^{1}$, Achmed Sukendro ${ }^{1}$, Rio Khoirudin Apriyadi ${ }^{1}$, and Dandung Ruskar ${ }^{1}$ \\ ${ }^{1}$ Disaster Management Study Program, National Security Faculty, Republic of Indonesia Defense University. IPSC Sentul \\ Area, Bogor, West Java, Indonesia
}

\begin{abstract}
Pidie Jaya (Piday) District of Aceh Province is a newly formed district in 2007. In addition to the COVID-19 pandemic, the Pidie Jaya district also experienced a series of disasters throughout 2020. Nevertheless, the Piday District Human Development Index (HDI) in 2017 exceeded the National achievement. But piday district poverty ranks 3rd in the Province. This has the potential to make the Piday district prone to disasters in addition to geographical location factors. Therefore, the existence of such gaps in this study will be discussed. This study uses qualitative methods through descriptive narrative approaches. Sources of information and data were obtained through Focus Group Decision (FGD) from several sources and studies of some literature. The results stated that the gap is due to economic development being less evenly distributed and less felt by lower-level people. This is due to low education factors and lack of capital for farmers and fishermen as the majority of workers in Piday District. The research suggests increasing community capacity and resilience by 1) Improving the quality of human resources for farmers and fishermen in the form of education and training based on improving the economy and living standards of farming communities wrapped in local wisdom; 2) Infrastructure development both facilities and infrastructure; 3) Provision of capital and ease of access in business and insurance coverage against disasters by taking into account local wisdom; 4) Empowerment of the role and involvement of local community leaders in the formulation of policies and local government institutions.
\end{abstract}

\section{Introduction}

As a country with the most islands in the world, Indonesia has abundant natural beauty and wealth. However, behind the beauty and natural wealth it has, Indonesia turns out to have a potential threat to natural disasters that are quite risky. When inaugurating the Opening of the 2021 National Coordination Meeting for Disaster Management on March 3, 2021, the President of the Republic of Indonesia Joko Widodo said that Indonesia was ranked 35 th in the world as the country most prone to disaster risk. It was also emphasized that mitigation efforts are the main focus of disaster management [1].

According to data from BNPB, throughout 2021 Indonesia has experienced 1.472 disaster events from January to June 24 [2]. The most dominant disasters are disasters caused by hydrometeorological factors, especially floods, as shown in the infographic on the distribution of natural disasters in Indonesia in 2021 in Fig. 1.

Various threats of disasters, both natural and manmade, exist in the life cycle of the entire Indonesian nation, which can directly hinder the smooth progress of development and the results achieved [3].

\footnotetext{
* Corresponding Author: riskina.tri@gmail.com
}

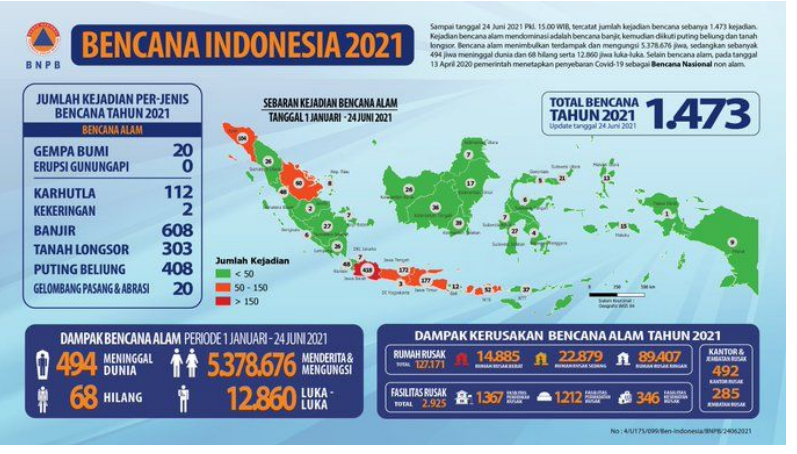

Fig. 1. Infographics on the distribution of natural Disasters, January 1 - June 24, 2021 [2].

President of the Republic of Indonesia in Law 24/2007 states that anyone has the right to a sense of security, especially those affected by disasters [4]. This shows that human security against the threat of disaster is a major concern. Given the nature of Indonesia's defense is that national defense is universal, and its implementation is based on an understanding of the rights and obligations as citizens and trust in their fighting power [5]. National 
security is no longer the content of war, nor is it a threat or defense of combatants, and non-combatants against all sectors of the state or foreign military attacks, but related to the security of all sectors that threaten human survival [6].

Geographically, Aceh Province is on the island of Sumatra which is also a meeting area between the Eurasian and Indo-Australian plates, and the existence of a living fault "The Great Sumatra Fault" or the Sumatran Fault cuts Sumatra from Semangko Bay to Aceh Province and extends to the Andaman Sea [7]. Some faults divide Aceh Province, both active and inactive, making Aceh Province a disaster-prone area [8]. At the end of 2016, the province of Aceh was again shaken by the occurrence of two earthquakes in the same month. The disaster resulted in 104 deaths, distributed in 3 (three) districts, namely Piday, Bireue, and Pidie districts. The most victims were in Piday Regency, which was 97 people and also caused tremendous damage to community housing, infrastructure, and socio-economic community [9].

The entire area of Piday Regency which includes 8 sub-districts, 222 villages, and 34 settlements is a disasterprone area, especially earthquakes. This is because Sumatra is located at the intersection of three major faults in the world, namely Australia, Eurasia, and the Pacific Plate [10]. The same thing was conveyed by the Aceh Social Service in the 2020 Psychosocial Support Service Training of Trainer event in Banda Aceh on Wednesday 11 March 2020 which stated that Aceh Province is a disaster-prone province, due to the geological and geographical environment of Aceh Province which is in the middle of a disaster. Ring of fire, making several volcanoes and subduction zones the epicenters of earthquakes and tsunamis. Aceh is also prone to flash floods, landslides, floods, and droughts. Others pointed out that the disasters that caused the most serious casualties were floods, landslides, and flash floods [7].

This incident finally placed Piday District as the third rank in Aceh Province in terms of poverty. However, from all regencies in Aceh Province, it turns out that Piday Regency has an HDI that continues to increase even above the Aceh Province and National HDI. It was recorded that in 2017, the HDI of Piday Regency was at an index of 71.73 while the Provincial HDI was 70.60 and the National HDI was 70.81 [9].

Based on the above background, the researcher finally conducted a study on the causes of the gap between poverty and HDI in the Piday Regency community in this COVID-19 pandemic situation. According to disaster risk analysis, the vulnerability index is exponentially in line with risk, which means that the greater the vulnerability index, the potential risk also increases and vice versa. And the HDI value, which is categorized by researchers as capacity, has an inverse relationship to threats. Where the higher the HDI, the smaller the vulnerability of an area, in this case, is poverty in Piday Regency.

\section{Method and Data}

This research is qualitative research using a descriptive narrative sentence approach based on the results of seminars and questions and answers with resource persons in the form of Focus Group Decisions (FGD). The resource persons in this study came from the Aceh Besar Geophysics Station, Piday Kodim, Regional Disaster Management Agency (BPBD), Regional Central Statistics Agency (BPS), Regional Development Agency, Community Social Institutions, and from academics of disaster experts at Syiah Kuala University, Piday Regency. Meanwhile, the data used in this study are intended as supporting material in providing an overview and evaluation of the social and economic vulnerability index and its relationship to the HDI. Social and economic vulnerability data based on information from informants will focus on poverty levels, types of work, and local wisdom because the index has a large influence. Literature review of several kinds of literature is intended to provide a more realistic picture and explanation to strengthen and deepen information from the informants.

\section{Result and Discussion}

\subsection{Socio-Economic Life of the People of Piday Regency}

Piday Regency which is located in the Aceh Province is one of the regencies that can be said to be still new. It is a division of Pidie Regency and was formed through Law $7 / 2007$ on January 2, 2007. The area of the Regency is. Piday is $1,162.84 \mathrm{~km} 2$ (952 km2 land and $210.84 \mathrm{~km} 2$ ocean). The Pidie Regency government oversees 8 subdistricts, 34 settlements, 222 gampongs, and 600 hamlets [11].

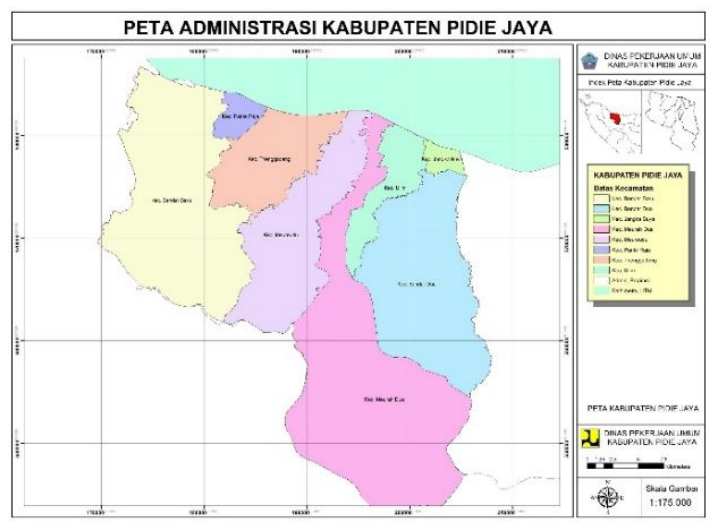

Fig. 2. Administration Map of Pidie Jaya Regency [12]

Through FGD seminars with sources from the Social Service of Piday Regency, it can be seen that the profession of work, poverty, and local wisdom have a great influence on the socio-economic vulnerability of the community. In addition, other information provided is that the majority of the Piday community depends on agriculture, fisheries, and forestry for their livelihoods. Along with this information, the Piday Regency Disdukcepatl data also explains that indeed the majority of the Piday Regency people's livelihood is working as farmers and fishermen in fulfilling their daily needs as 
shown in Table 1. This is due to the geographical conditions of the area that support the profession [9].

Table 1. The Majority of Professions/Livelihoods of the Population of Pidie Jaya Regency 2018 [9].

\begin{tabular}{|c|c|c|}
\hline Profession/Livelihood & Total & $\mathbf{\%}$ \\
\hline Farmers/Growers & 16.913 & 10,56 \\
\hline Fisherman & 7.907 & 4,94 \\
\hline Marketer & 2.686 & 1,68 \\
\hline Entrepreneur & 15.510 & 9,69 \\
\hline Civil Servants & 3.461 & 2,16 \\
\hline TNI/POLRI & 509 & 0,32 \\
\hline Employee/Honorary & 1.864 & 1,16 \\
\hline Others & 5.767 & 3,60 \\
\hline Housewife, Students & 105.498 & 65,89 \\
\hline Toddler (Unemployed) & $\mathbf{1 6 0 . 1 1 5}$ & $\mathbf{1 0 0 , 0 0}$ \\
\hline Total Population & &
\end{tabular}

The following information obtained from the FGDs is that the poverty rate in Piday District is $19 \%$, ranks third in Aceh Province, and is still considered high. The Central Statistics Agency (BPS) noted that since 2002, Aceh Province has been the poorest area in Sumatra [13]. Sharp poverty began to be felt in 2000 - 2004 due to the occurrence of armed conflict and the 2004 Tsunami [14].

Eka Agustina (2018) concludes that poverty in Aceh province is influenced by the level of education and unemployment rate while the population does not affect poverty so that the government must improve the education and skills of the workforce through training to improve the quality of human capacity so that they are competitive to get jobs. , so as not to fall into poverty [15]. The difficulty of opening a business field and being constrained by capital and marketing capabilities are the main factors causing regional unemployment [9].

The 2004 Aceh tsunami disaster greatly affected the socio-economic life of the Acehnese. The Acehnese were forced to rebuild their lives after the tsunami hit. Specifically, in Pidie Jaya on December 7, 2016, an earthquake occurred centered in Pidie Jaya. The disaster left hundreds of people dead and thousands of people affected. Economic losses are estimated at billions of rupiah [16]. The geographical area of Pidie Jaya Regency is prone to disasters, resulting in a lack of interest from investors to invest in Pidie Jaya Regency. So that in terms of trade economy, the Pidie Jaya Regency area is still classified as underdeveloped [17].

In general, $70 \%$ of Piday people in rural areas work in agriculture. In the aftermath of the 2004 tsunami, restoration and reconstruction work had been carried out for nearly a decade with a budget of nearly one trillion, including the construction of housing and public buildings for the people affected by the tsunami. The improvement of infrastructure and the community's economy (community livelihoods) with the restoration of the agricultural and fisheries sectors has led to various improvements in Aceh's fisheries and agricultural potential in many ways. Although the impact on the wider community is not significant and does not provide a stronger role for economic growth, income, and welfare, as well as the maintenance of people's lives [18].
In the context of regional economic development, Aceh's coastal and maritime capacity management requires strategies and controls on ecosystem sustainability. This is reflected in local wisdom in marine protection. The wisdom of Acehnese fishermen in protecting the sea is included in the customary rules of the Aceh fishing community. The Commander of the navy is responsible for leading the customary associations that govern maritime customary law. Maritime customary law is formulated under Islamic law which guarantees regulations for the exploitation of maritime wealth (meupayang), equitable distribution of profits, determines the schedule for catching marine fish, enforces customary rules and rituals, raises fishermen, and resolves problems among fishermen. Rules in resolving maritime disputes and violations, warnings and sanctions for seafarers who violate maritime rules, and relations between fishermen and local governments. [19].

In addition, Piday Regency also has local wisdom called "Meureukon" which is a method of religious education or da'wah about religious knowledge based on the Koran. Meureukon is one of the traditions and local wisdom of the Piday community. There are no restrictions on the number of members, age, and gender in Meureukon. The special feature of Meureukon is the use of the Koran in the explanation of religious knowledge with the material as a whole adapted and associated with Islamic religious law. Meureukon activities are usually held in the framework (pendopo), so it is also said to be a debate event in the Tengku Rangang style. However, it usually starts after the Maghrib prayer and stops at the meunasah (surau) before the dawn prayer. Meureukon activities are not just a means of broadcasting or a means of Islamic da'wah, but there are values of religious education, unity, society, and aesthetics in Meureukon which have been applied in people's lives. Meureukon also has a function, namely as a means of expression, ritual, communication, and entertainment [20].

The people of Pidie Jaya Regency also have local wisdom in the form of the Peusijeuk Tradition, which is a tradition in the form of a tradition to ask for safety, peace, and happiness in life [21]. This tradition is carried out during wedding ceremonies, performing Hajj, about to migrate, commemorating the birth of a child, or to commemorate something happiness that is obtained, such as when a family member earns a bachelor's degree. This tradition can strengthen the social ties that exist in the Pidie Jaya community which is expected to be able to increase the socio-economic level of the community [22].

\subsection{Piday District Human Development Index}

Indonesia's HDI in the early days of the COVID-19 pandemic compared to previous years grew by 0.03 percent (an increase of 0.02 points). This slowdown in growth is strongly influenced by the decline in per capita expenditure due to the COVID-19 pandemic. Based on the performance achievements of the Piday district government since 2011 that the HDI has reached 68.69 and in 2015 it increased to 70.49 in 2016 and 2017 by 71.73 with the calculation of the new method. The HDI of 
the Piday Regency is increasing every year. Similarly, when compared to the Provincial HDI in 2015 of 69.45 , it increased to 70.00 in 2016 and 2017 to 70.60 (table 2). In general, it can be seen that the HDI of the Piday Regency is always above the Aceh and National HDI [9].

Table 2. Pidie Jaya District HDI 2011-2017 [9]

\begin{tabular}{|c|l|c|c|c|c|c|c|}
\hline No & Descrip- & \multicolumn{7}{|c|}{ Year } \\
\cline { 3 - 8 } & tion & $\mathbf{2 0 1 2}$ & $\mathbf{2 0 1 3}$ & $\mathbf{2 0 1 4}$ & $\mathbf{2 0 1 5}$ & $\mathbf{2 0 1 6}$ & $\mathbf{2 0 1 7}$ \\
\hline 1 & $\begin{array}{l}\text { Pidie Jaya } \\
\text { District }\end{array}$ & 68,9 & 69,3 & 69,9 & 70,5 & 71,1 & 71,7 \\
\hline 2 & $\begin{array}{l}\text { Aceh } \\
\text { Province }\end{array}$ & 67,8 & 68,3 & 68,8 & 69,4 & 70,0 & 70,6 \\
\hline 3 & National & 67,7 & 68,3 & 68,9 & 69,5 & 70,2 & 71,8 \\
\hline
\end{tabular}

HDI includes three basic human components, namely life expectancy (Longevity), education (Knowledge), and decent living (Decent living). The achievement of the HDI that continues to increase is a positive sign of continuous improvement in the quality of the Piday community in terms of health, education, and economy. The high and low value of the human development index cannot be separated from the development plans implemented by the government. The achievement or increase in the number of HDI does not happen instantly. Human development is a method that cannot be measured right away. It is difficult to determine the health outcomes of education and development in the short term, which is generally the opposite of economic development. Communities with higher human development, especially those with good levels of education and health, are more resilient than those with less nutrition and less education. So that these vulnerable people will face difficulties in changing their fate when shocks or disasters occur. Human development will shape the strength of individuals and communities to reduce vulnerability and build resilience socially and economically [10].

\subsection{The HDI Gap and Piday Community Poverty}

With a high HDI value even higher nationally, it should be able to suppress and reduce poverty in Pidie Jaya and at the same time increase resilience to natural disasters that often occur. The entire area of Piday Regency is a disaster-prone area. Various disasters ranging from earthquakes, tsunamis, floods, strong winds, erosion, volcanic eruptions, landslides, forest fires, and abrasion will always be a threat. On February 16, 2017, at 02:53 WIB, there was an earthquake with a value of 5.4 on the Richter Scale at a depth of $12 \mathrm{~km}$, located at latitude 5.21 96.13 East Longitude, $9 \mathrm{~km}$ northwest of Piday with 97 fatalities. Another disaster that recently occurred was the flood disaster in April 2020 amid the Covid-19 pandemic which resulted in material losses [9]. And based on information from sources, disasters that often occur are floods. One of the high negative impacts of disasters is believed to be related to the vulnerability of low-income communities [23].

However, the high HDI value of Pidie Jaya is not in line with the existing poverty rate. Through research conducted by Suliswanto (2010) concluded that the HDI variable has the greatest influence on poverty [24]. A high
HDI value will reduce the poverty rate. The high HDI which is not in line with the poverty rate shows that economic growth still does not provide many benefits for lower-income people. However, a surge in the quality of human resource capacity will have a major impact on reducing poverty. For this matter, the solution is to form a just and equitable economy for the poor to ensure the fulfillment of basic needs and to encourage secondary and tertiary needs. Based on the experience of economic development from developed countries in Asia such as Taiwan, Singapore, South Korea, and Hong Kong, it has been proven that the direction of investment towards improving human resources (through the education process) is more "effective" than physical investment (buildings, other infrastructure) [24]. This happens because the poverty of an area can also be caused by the quality of the population. Even with the construction of road materials, factories, hospitals, and others, if the quality of the population is not high, then the material capital cannot be utilized optimally [25]. This shows that there is a relationship between economic growth and poverty with HDI. In addition to the quality of human resources, another factor that affects poverty according to Susilowati (2015) is the debt factor. It is concluded that there is a mutually influencing relationship between debt factors, economic growth, and poverty. So that in carrying out economic development, the Government should pay attention to these three variables [26].

Judging from the geography of Pidie Jaya Regency which has abundant natural resources, poverty should not be a problem in the people of Piday Regency where the majority of their livelihoods are farmers and fishermen. Based on the results of research conducted by Usman (2020) it is concluded that there are obstacles in the maritime sector to be able to develop. The fishing communities, toke, and crew fishermen in Pidie Jaya have lost their jobs sharply. This causes unemployment in a very short time because the income of fishermen only depends on the sea as the sole employment sector. Based on the results of interviews conducted, it turned out that the fishermen asked to be allowed to re-install FADs in the areas that had been cut. In addition, payments for FADs that have been cut are expected to be paid as soon as possible so that they can be used for preparation for the manufacture of new FADs. Fishermen also ask for compensation in the form of empowerment, necessities, and side dishes [27].

Other obstacles faced include natural factors due to climate change, high prices of fuel oil (BBM), and shallow fish-selling points (TPI), which make large vessels unable to dock so they cannot directly carry out fish trading transactions. Meanwhile, from the work of farmers, Adhiana (2017) concludes that the factors causing the vulnerability of farming communities in Aceh province are the level of education and access to financial credit. Other factors such as the number of productive age, health, culture, and the role of traditional institutions have a significant influence on the resilience of farmers. This is because these factors also affect poverty. The higher the index of these factors, the more it can suppress and reduce the poverty rate so that the resilience of farmers in dealing with disasters will increase [28]. 


\section{Conclusion}

The influential socio-economic vulnerabilities in the people of Piday Regency are the high poverty rate and type of work. Cultural factors, religion, and local wisdom reduce the level of socio-economic vulnerability. Poverty and type of work have a big influence on the impact of disasters both during pre-disaster to post-disaster considering that the majority of types of work are based on existing geographical conditions.

In general, the poverty of the Piday community is caused by the quality of the human resource capacity which is minimal in terms of knowledge. In addition, the existence of debt and economic growth that is not under the existing physical development is considered to be of little benefit to the community. So based on this, there is a relationship between poverty and HDI and there is still a gap between the high HDI in Piday Regency and the existing economic growth. Theoretically, with the increase in HDI, economic growth will also increase and it is expected to reduce poverty, but this does not apply in Pidie Jaya Regency. The poverty that occurs in fishermen is making the fishing profession a single profession, inadequate market access, and lack of business capital so that it increases the number of unemployed. An increase in the number of unemployed will eventually increase the poverty rate and increase the needs of fishermen for basic needs. From the agricultural sector, farmers experience poverty vulnerability at the level of education and access to business credit. It can be concluded that farmers and fishermen collectively have poverty vulnerabilities in terms of education and business capital.

\section{Suggestion}

As input material that can be given by the author to build the socio-economic life of the community in Piday Regency so that it is in line with economic development so that it will increase community capacity and be resilient in facing disasters, namely: 1) Infrastructure development, both facilities and infrastructure, and economic distribution must consider the prosperity the surrounding community, especially farmers and fishermen as well as local wisdom that exists in the community; 2) Improving the quality of human resources for farmers and fishermen in the form of education and training based on improving the economy and standard of living of the community wrapped in local wisdom; 3) Provision of capital and ease of access in business and insurance coverage against disasters by taking into account local wisdom; 4) Empowerment of the role and involvement of local community leaders in policy formulation and local government institutions.

\section{References}

1. Humas, (2021)

2. BNPB, (2021)
3. D. Putra, Disaster Management and National Defense (2012)

4. RI, Law Number 24 of 2007 Disaster Management (Government of the Republic of Indonesia, Jakarta, 2007)

5. RI, Law Number 23 of 2019 Management of National Resources for National Defense (Government of the Republic of Indonesia, Jakarta, 2019)

6. A. Mack, Die Friedens-Warte 80, 177 (2005)

7. I. Rusydy, (2013)

8. M. Affan, M. Syukri, L. Wahyuna, and H. Sofyan, Aceh Int. J. Sci. Technol. 5, 54 (2016)

9. Pidie-Jaya, Qanun of Pidie Jaya Regency Number 3 of 2020 Concerning the Medium Term Development Plan (RPJM) of Pidie Jaya Regency for 2019-2024 (Pidie Jaya Regency Government, Aceh, 2020)

10. Pidie-Jaya, Qanun of Pidie Jaya Regency Number 1 of 2018 Concerning the Long-Term Development Plan (RPJP) of Pidie Jaya Regency for 2015-2035 (Pidie Jaya Regency Government, Aceh, 2015)

11. N. Nurjanah, J. Pengabdi. Kpd. Masy. 19, 68 (n.d.)

12. D. P. Pidie Jaya, Pidie Jaya District Administration Map (2011)

13. C. G. Asmara, (2021)

14. Safrina, (2021)

15. E. Agustina, M. N. Syechalad, and A. Hamzah, J. Perspekt. Ekon. Darussalam 4, 265 (2018)

16. M. Fadri, M., \& Zuhri, J. Ilm. Mhs. Bid. Huk. Kenegaraan 2, 336 (2018)

17. L. J. Aji, D. P. Meiliasari, R. K. Apriyadi, S. Maarif, and H. Sumantri, PENDIPA J. Sci. Educ. 6, 64 (2022)

18 A. Graf, S. Schroter, and E. P, Aceh: History, Politics, and Culture (Institute of Southeast Asian Studies, Singapore, 2010)

19. E. Apriana, Serambi Saintia J. Sains Dan Apl. 4, (2016)

20. F. Fitria, R. Ramdiana, and I. Ismawan, J. Ilm. Mhs. Pendidik. Seni, Drama, Tari Musik 4, (2019)

21 T. Rahayu, L. J. Aji, A. Suta, A. Hergani, A. Fitria, R. N. Utami, and S. V. Vidyaningsih, Int. Invent. Innov. Compet. 2, 54 (2017)

22. N. Noviana, DESKOVI Art Des. J. 1, 29 (2018)

23. W. Adiyoso, Disaster Management: Introduction and Strategic Issues (Bumi Aksara, Jakarta, 2018)

24. M. S. W. Suliswanto, J. Ekon. Pembang. 8, 357 (2010)

25. M. L. Jhingan, (2016)

26. D. Susilowati and M. S. W. Suliswanto, J. Innov. Bus. Econ. 6, 89 (2015)

27. U. Usman and M. Nur, J. Serambi Akad. 8, 1671 (2020)

28. A. Adhiana, Agrifo J. Agribisnis Univ. Malikussaleh 2, 34 (2017) 